\title{
DESCRIPTION AND INTERPRETATION OF CENOZOIC VERTEBRATE ICHNOFOSSILS IN RIO GRANDE DO SUL STATE, BRAZIL
}

\author{
HEINRICH THEODOR FRANK, LEONARDO GONÇALVES DE LIMA, \\ NICOLI POZZEBON GERHARD
}

Instituto de Geociências, UFRGS, Campus do Vale, 91501-970, Cx.P. 15001, Porto Alegre, RS, Brasil. heinrich.frank@ufrgs.br, paleonardo_7@hotmail.com,nicoligerhard@gmail.com

FELIPE CARON

Universidade Federal do Pampa. Av. Pedro Anunciação, s/n, 96570-000,

Caçapava do Sul, RS, Brasil. caronfelipe@yahoo.com

FRANCISCO SEKIGUCHI DE CARVALHO BUCHMANN

Laboratório de Estratigrafia e Paleontologia, UNESP, Unidade São Vicente, Campus do Litoral Paulista, 11330-900, São Vicente, SP, Brasil.paleonchico@yahoo.com.br

\section{MILENE FORNARI}

Instituto de Geociências, USP, Rua do Lago, 05508-080, São Paulo, SP, Brasil.milenefornari@yahoo.com.br

\author{
RENATO PEREIRA LOPES \\ Instituto de Oceanografia, FURG, Campus Carreiros, Av. Itália, km 08, \\ 96201-900, Rio Grande, RS, Brasil.paleonto_furg@yahoo.com.br
}

\begin{abstract}
In the neighborhood of the city of Boqueirão do Leão (State of Rio Grande do Sul, Brazil) a set of three big-sized tunnels has been found. One of the tunnels is only partially filled with sand and accessible along its entire length. It is horizontal, slightly sinuous, $36 \mathrm{~m}$ long, up to $4.2 \mathrm{~m}$ wide and up to $2.0 \mathrm{~m}$ high. The surface morphology of the walls is composed of anthropogenic marks, speleothems, black incrustations and traces like digging scratches and smoothed surfaces. The $2^{\text {nd }}$ tunnel has its entrance blocked by sand and sandstone cobbles, but the end of the tunnel is only partially clogged and therefore accessible. This accessible portion is $12 \mathrm{~m}$ long, $3 \mathrm{~m}$ wide and $1.5 \mathrm{~m}$ high. The $3^{\text {rd }}$ tunnel is completely filled and collapsed and is nowadays only indicated by concave roof features at its end. The general features of the tunnel system and the analysis of the surface morphology of the walls of the accessible portions permit to conclude that the tunnels were produced by ground sloths of the Cenozoic South American megafauna. The size of the tunnels suggests that its excavation was gradually carried out by successive generations of sloth herds, and not by a single individual animal. The primary function of the tunnels probably was not protection from predators, which had easy access to structures of this size, but to shelter during a drier climate. However, it is not yet possible to relate the tunnels to a specific ground sloth genus, a task that depends on the discovery of better-preserved tunnel systems.
\end{abstract}

Key words: paleovertebrates, South America, burrows, ichnofossils, megafauna, ground sloths.

RESUMO - Nas imediações da cidade de Boqueirão do Leão (Estado do Rio Grande do Sul, Brasil) foi encontrado um conjunto de três túneis de grande porte. Um dos túneis está apenas parcialmente preenchido com areia e acessível em toda a sua extensão, sendo horizontal, levemente sinuoso com $36 \mathrm{~m}$ de comprimento, largura de até $4.2 \mathrm{~m}$ e altura de até $2 \mathrm{~m}$. A morfologia das paredes do túnel é composta por marcas antropogênicas, espeleotemas, incrustações pretas e marcas de paleovertebrados como marcas de escavação e superfícies alisadas. O segundo túnel tem sua entrada bloqueada por areia e seixos de arenito, mas a porção final do túnel está apenas parcialmente preenchida e, portanto, acessível. Esta porção acessível possui $12 \mathrm{~m}$ de comprimento, $3 \mathrm{~m}$ de largura e 1,5 m de altura. O terceiro túnel está completamente preenchido e desabado e pode ser reconhecido atualmente apenas pelas feições côncavas do teto em seu final. As características gerais do sistema de túneis e a análise da morfologia das paredes das porções acessíveis permite concluir que os túneis foram produzidos por preguiças terrestres da Megafauna Cenozoica sul-americana. O tamanho dos túneis sugere que sua escavação foi gradual, realizada por gerações sucessivas de grupos de preguiças, e não por um animal individual. A função primária dos túneis provavelmente não foi proteção de predadores, que tinham fácil acesso a estruturas desse tamanho, mas abrigo durante um clima mais seco. Entretanto, ainda não é possível relacionar os túneis a um gênero específico de preguiça terrestre, o que depende da descoberta de sistemas de túneis melhor preservados.

Palavras-chave: paleovertebrados, América do Sul, paleotocas, icnofósseis, megafauna, preguiças-terrestres. 


\section{INTRODUCTION}

Domichnia-type ichnofossils (Seilacher, 1953) encompass tunnels or chambers that serve as semipermanent domiciles, made by burrowing organisms such as mollusks, worms and crustaceans (e.g. Bromley, 1990; Buatois \& Mángano, 2011). Several living terrestrial vertebrates can produce such structures, such as armadillos, moles and prairie dogs. The tunnels produced by fossorial paleovertebrates, on the other hand, are increasingly receiving attention, being recognized in growing numbers. Tunnels produced by vertebrates during the Paleozoic and the Mesozoic have been described, for example, in Africa (e.g. Smith, 1987; Groenewald, 1991; Modesto \& Botha-Brink, 2010; Voigt et al., 2011), in Europe (e.g. Popa \& Kedzior, 2006; Talanda et al., 2011), in North America (e.g. Varrichio et al. 2007; Storm et al., 2010; Riese et al., 2011), in Antarctica (e.g. Miller et al., 2001; Sidor et al., 2009) and in Australia (e.g. Martin, 2009). These structures were found completely filled with sediments; attain maximum diameters of $0.5 \mathrm{~m}$ and lengths of up to $5.5 \mathrm{~m}$.

In South America, however, late Cenozoic fossorial vertebrates were responsible for the excavation of much bigger tunnels. These tunnels may present widths of around $4 \mathrm{~m}$, heights of $2 \mathrm{~m}$ and lengths of many tens of meters. When well preserved and accessible, it is possible to confirm that the tunnels form complex multi-storey systems with several openings to the surface and summed tunnels lengths of several hundreds of meters. From the entire set of tunnels found so far, only some $25 \%$ are not completely filled with sediments, allowing research of the surface morphologies of the tunnel walls.

The South American tunnels are the biggest ichnofossils and probably the best-preserved paleovertebrate burrows of the world. Occurrences in Argentina were described and interpreted by Quintana (1992); Zárate et al. (1998); Vizcaíno et al. (2001) and Dondas et al. (2009). In Brazil, the first mention of a tunnel was that of Padberg-Drenkpol (1933), followed by tens of records in the archaeological literature, which described the tunnels as anthropogenic structures, excavated by native people in pre-colonial times (e.g. Rohr, 1971; Prous, 1991, p. 318). Its reinterpretation as paleovertebrate tunnels started with J.A. Villwock, of the Universidade Federal do Rio Grande do Sul, whose information based the article of Bergqvist \& Maciel (1994). In 2003, a specialized team was formed on the exploration of the tunnels. This resulted in an exponential growth of the amount of information available (e.g. Buchmann et al., 2003, 2009).

This contribution is devoted to the description and interpretation of the features of a set of tunnels excavated by Cenozoic vertebrates in the South of Brazil. These tunnels are outstanding due to their degree of preservation, good accessibility and dimensions. Thus, the occurrence establishes reliable interpretative criteria for other similar tunnel systems and allows establishing possible life habits of the fossorial paleovertebrates, a finding only possible in very isolated instances when dealing with large paleovertebrates.

\section{MATERIAL AND METHODS}

A set of several hundred paleovertebrate tunnels was found in Brazil, most of them ( $70 \%)$ completely filled with sediments. Prospecting methods include own fieldwork by our research group, the distribution of pamphlets, and the use of the knowledge of park rangers of protected lands, of the database of the State Rabies Control Program and of the archaeological literature. Some tunnels have been explored using an auger and lowering, through the hole, a probe with a headlight and a webcam connected to a notebook to shot pictures of the tunnel. The main tunnel (Tunnel A) described in this contribution was found through digital prospecting of "cave" descriptions and pictures in the Internet.

The location with one or more paleovertebrate tunnels undergoes a methodic data collection scheme (Figure 1), including the analysis of lengths, widths and heights, surface structures on the walls and others. The search for fossils inside the tunnel was yet unsuccessful, but the possibility of its occurrence always is considered.

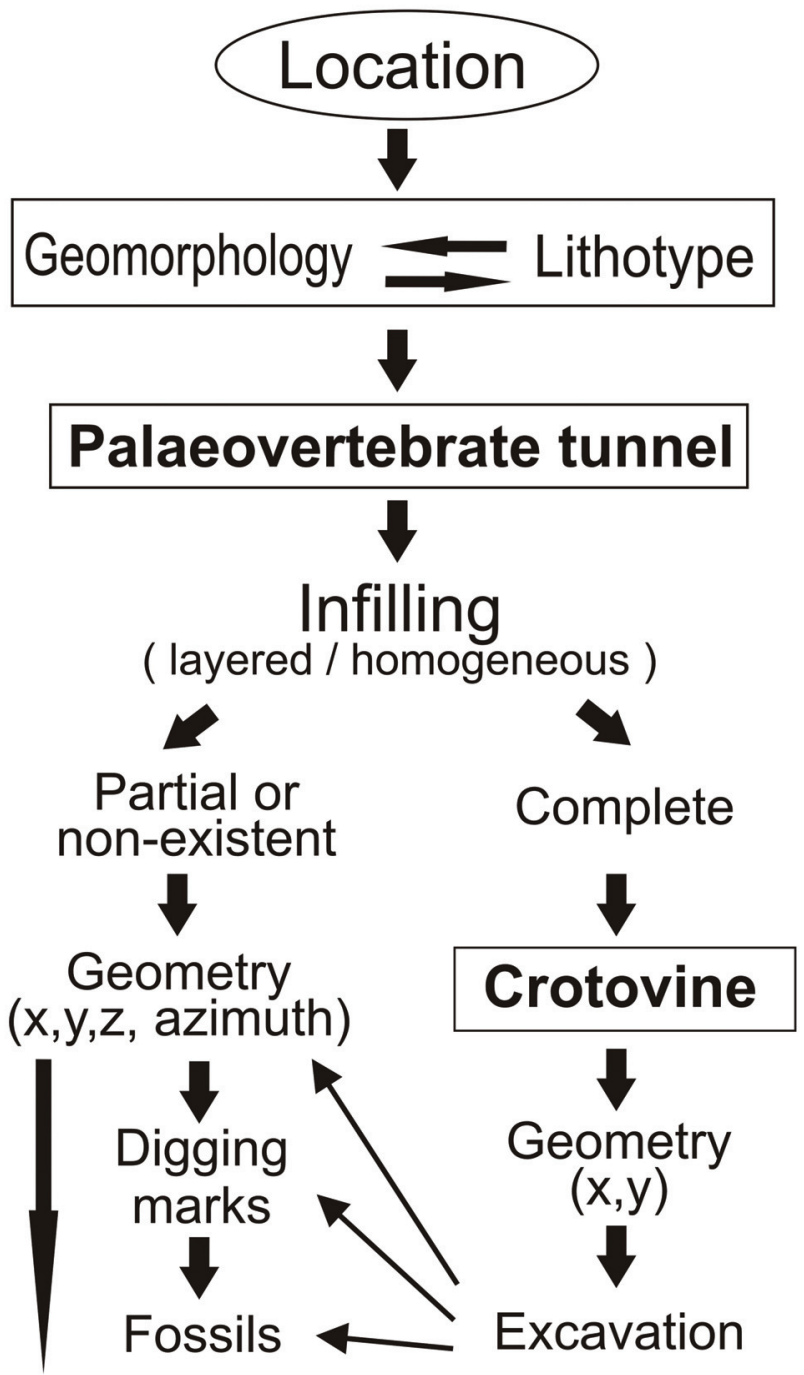

Figure 1. Data collecting scheme of paleovertebrate tunnels, step by step. 


\section{GEOLOGICAL SETTING}

The geology of southern Brazil, comprising the states of Rio Grande do Sul, Santa Catarina and Paraná (from south to north), is based on three main domains (Figure 2). The first domain corresponds to the Precambrian basement that crops out as a narrow strip approximately parallel to the Atlantic coast. The dominant rocks are granites and gneiss with subordinated schists (e.g. Bitencourt \& Nardi, 2000; Bitencourt et al., 2008)

The 1.2 million $\mathrm{km}^{2}$ intracratonic Paraná basin (Milani et al., 1998) corresponds to the second domain and is found westwards of the Precambrian basement. This basin is filled with a lower sedimentary and an upper volcanic succession. The sedimentary sequence encompasses units of Late Ordovician to Cretaceous in age; it is composed by a dozen of continental and marine strata formed by mudstones, sandstones, and coal seams and may reach a thickness of
$3.5 \mathrm{~km}$. This section is toppled by the $1.7 \mathrm{~km}$ thick lava flows of the Early Cretaceous Serra Geral Formation, which constitutes most of the Paraná-Etendeka Continental Flood Basalt Province, and show some intercalated sedimentary (sandy) interflow deposits (Peate, 1997; Self et al., 1998). In most of the basin, the sedimentary rocks crop out along the borders and the volcanic rocks cover $\sim 900.000 \mathrm{~km}^{2}$ of the central region (Frank et al., 2009).

Finally, to the east of the basement are located the recent coastal plains, corresponding to the subaerial sections of the marginal basins that form the continental shelf. These plains, of Quaternary age, were formed by sea-level changes. These units may have widths of more than $100 \mathrm{~km}$ and lengths of several hundred kilometers, as in the southernmost state of Rio Grande do Sul (Villwock et al., 1986), or are almost absent as in the two Northern states. They are composed of unconsolidated sands with subordinated gravel and lacustrine deposits (clays and peat). Paleovertebrate tunnels have

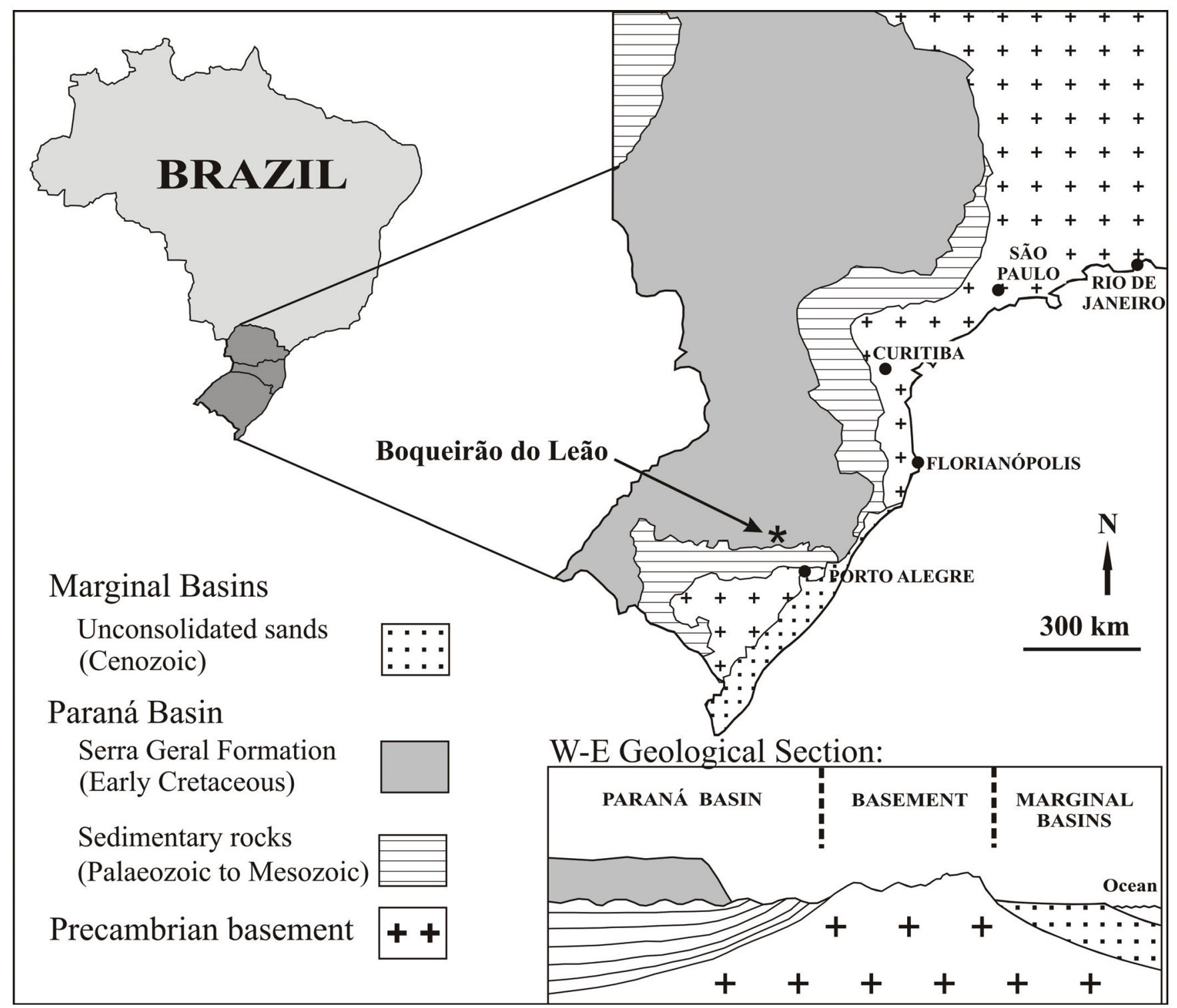

Figure 2. Regional geologic context. Top left, location map of the three Southern Brazilian states. From bottom to top: Rio Grande do Sul, Santa Catarina and Paraná. Top right, regional geological outline. The city of Boqueirão do Leão is indicated. Modified from Mercosul (2001). Bottom right, simplified geological W-E section, not to scale. 
been found in the three domains, excavated in sediments, sedimentary rocks and weathered igneous and metamorphic rocks. Generally the tunnels are located in areas of moderately undulated relief, not in plains or in areas of very rugged relief.

\section{STUDY AREA}

The Boqueirão do Leão paleovertebrate tunnels are located on the property of Laudir Ogliari in the locality of Sinimbuzinho, municipality of Boqueirão do Leão (State of Rio Grande do Sul, Brazil), at the coordinates $29^{\circ} 19^{\prime} 24^{\prime \prime} \mathrm{S}$, $52^{\circ} 26^{\prime} 17.4^{\prime \prime} \mathrm{W}$, at an altitude of around $440 \mathrm{~m}$ (Figure 2).

The region of Boqueirão do Leão is covered by the Serra Geral Formation, the package of volcanic rocks which occupies the upper portion of the Paraná Basin (Peate, 1997). Geomorphologically, the region is composed by a dissected plateau, with altitudes ranging between 420 and $650 \mathrm{~m}$. The highlands are composed of thick $(>50 \mathrm{~m}$ ) horizontal beds of volcanic rocks (rhyolites), whose interpretation as lava flows or as collapsing pyroclastic eruption columns is still not conclusive (Garland et al., 1995). The lowermost level of each one of these volcanic units presents a very conspicuous $1-10 \mathrm{~cm}$ spaced jointing, whose attitudes vary from horizontal to vertical depending on the cooling pattern of the rock and of the pre-existing relief (Figures $3 \mathrm{~A}, \mathrm{~B}$ ). Among the individual rhyolite units there are levels of altered rock, up to $20 \mathrm{~m}$ thick, whose upper irregularities formatted the base of the overlying rhyolite units (Figure 3C). In one of these altered levels was found a $3 \mathrm{~m}$ long and $0.7 \mathrm{~m}$ wide paleovertebrate burrow (Figure 3C, insert).

Fieldwork conducted in the region showed that an area of lower elevation within this region constitutes an extensive outcrop of sandstone of the Botucatu Formation $\left(\mathrm{J}_{\text {Sup }}-\mathrm{K}_{\mathrm{Inf}}\right)$, which is the unit located immediately below the volcanic rocks in the stratigraphic column. The sandstone is composed of reddish medium to coarse-grained sand, characteristic of continental environments with arid climates. Usually the sandstone presents a large-scale cross-stratification. Probably the sandstone area in Boqueirão do Leão does not represent the outcropping of a thicker or higher level of the underlying Botucatu Formation. As we have found, along the drainages, volcanic rocks at lower altitudes than the sandstone, the sandstone must be an aeolian intercalation between two successive units of volcanic rocks. Such intercalations are common in the Paraná Basin (e.g. Veiga, 1973; Jerram et al., 2000), attain thickness from a few $\mathrm{cm}$ to more than $100 \mathrm{~m}$ and show highly variable geometries. In the region of Boqueirão do Leão, the sandstone outcrop covers at least $1 \mathrm{~km}^{2}$ (Figure 4). The tunnel system described in this contribution was excavated in these sandstones of the Botucatu Formation. The sandstones are not altered and have a medium to high lithification degree.

\section{DESCRIPTION OF THE TUNNEL SYSTEM}

The tunnel system is composed by 3 tunnels, named A, B and $C$ (Figure 5). Tunnel A can be traversed in its entire length, while tunnel B has its front portion filled with sediments.
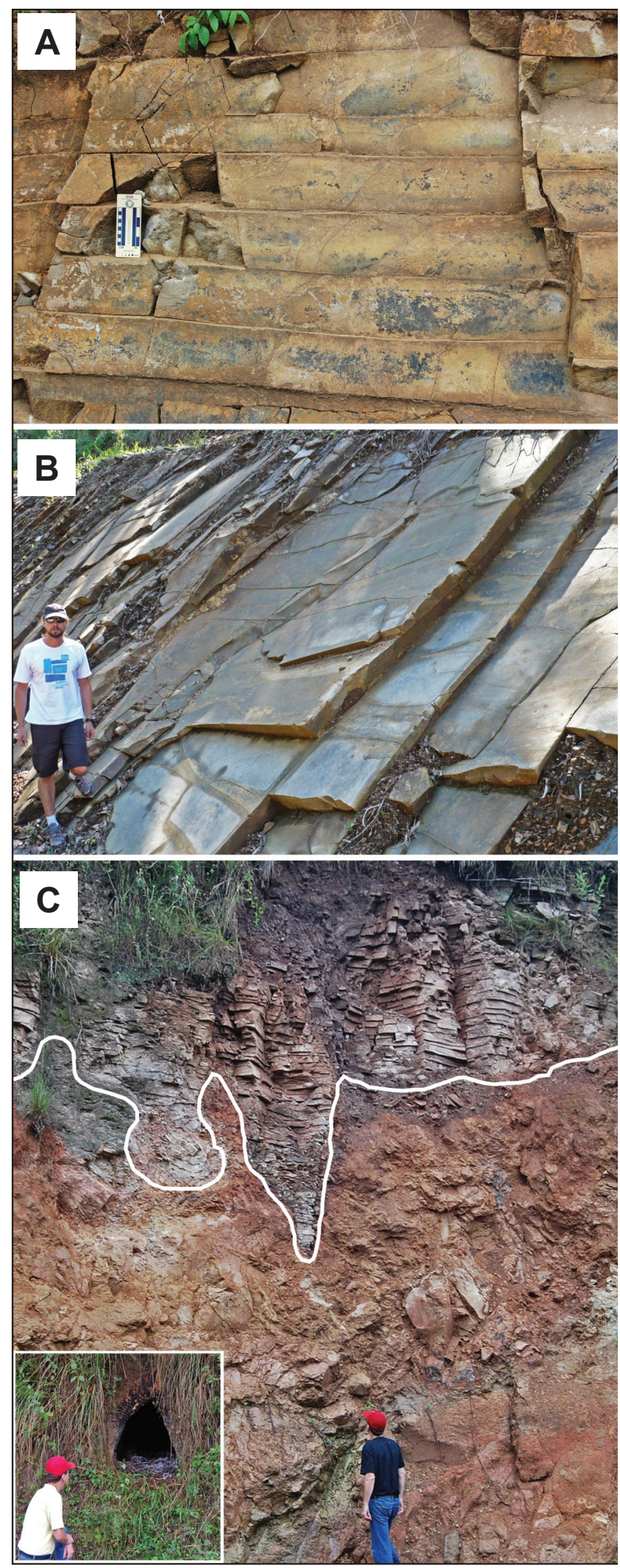

Figure 3. Aspects of the volcanic rocks in the region of Boqueirão do Leão. A, horizontal jointing in rhyolitic rocks. Scale bar $=10 \mathrm{~cm}$. $\mathbf{B}$, inclined jointing in rhyolitic rocks. Observer $=1.95 \mathrm{~m}$. C, irregular boundary (white line) between the horizontally-jointed base of the upper rhyolite level and the top of the lower rhyolite level, composed of altered rocks. Observer $=1.85 \mathrm{~m}$. Insert, in this kind of altered material a small paleovertebrate burrow was found (see text). 


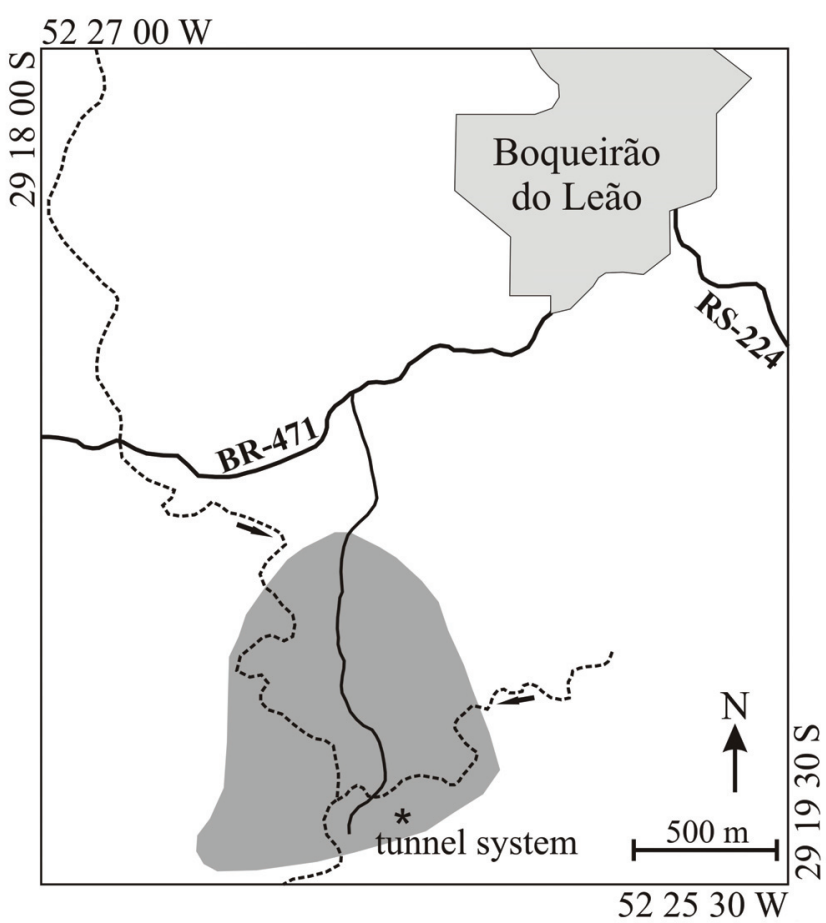

Figure 4. Location of the tunnel system of Boqueirão de Leão. The city of Boqueirão do Leão is in the north. There are two main roads (BR-471 and RS-224) and the drainages are marked with dotted lines. The whole region is covered by acid volcanic rocks (rhyolites). The dark area represents the minimum extent of the outcropping sandstone of the Botucatu Formation in which the tunnel system was excavated.

Tunnel $\mathrm{C}$ is completely filled and collapsed and was inferred due to the occurrence of concave surfaces at its end, which correspond to parts of the roof. Tunnels $\mathrm{A}$ and $\mathrm{C}$ are located at the same level, whereas tunnel $\mathrm{C}$ is at a lower level, with its roof some $50 \mathrm{~cm}$ below the floor of the upper tunnels.

\section{Tunnel A}

Tunnel A has its entrance situated on a gentle slope, only $80 \mathrm{~m}$ away from a small river (Figure 6A). It is sinuous, horizontal, oriented $\mathrm{NE}$ and $36 \mathrm{~m}$ long. The first $8 \mathrm{~m}$ nowadays lack any original feature (Figures $6 \mathrm{~B}, \mathrm{C}$ ). The width of the tunnel ranges between 3.6 and $4.1 \mathrm{~m}$ between the $8^{\text {th }}$ and the $13^{\text {th }} \mathrm{m}$; these numbers slowly decrease to 1.5 to $2.0 \mathrm{~m}$ in the final portion of the tunnel (Table 1). The tunnel is filled $40-50 \%(1 \mathrm{~m})$ by sand (Figure $6 \mathrm{E})$. The height of the tunnel is of 2.2-1.9 m between the $9^{\text {th }}$ and the $13^{\text {th }} \mathrm{m}$. In the filled portion of the tunnel, the open space varies in height between 0.8 and $1.0 \mathrm{~m}$.

Between the $8^{\text {th }}$ and the $15^{\text {th }} \mathrm{m}$, corresponding to the portion of the tunnel between the destroyed and the half-filled portions, the elliptical $2.2 \mathrm{~m}$ high and $4.1 \mathrm{~m}$ wide section of the tunnel is clearly visible (Figure 6D). There are no rock collapse features. Regarding its shape, the tunnel shows the typical domed form of a huge paleovertebrate tunnel (Figure $6 \mathrm{~F}$ ). At the end of the tunnel, several successive chambers can be recognized due to the occurrence of parts of the tunnel with coincident concave surfaces on opposite lateral walls (Figure 6G). The surface morphology of the tunnel walls is described below.
Anthropogenic action inside the tunnel started with the destruction of the original walls in the first $8^{\text {th }} \mathrm{m}$ by a treasure hunter. Around 1975, a couple of archaeologists worked inside the tunnel for a week, rescuing an Indian lithic artifact. From the $15^{\text {th }}$ to the $26^{\text {th }} \mathrm{m}$ a trench was excavated in the infilling (Figure 6F).

\section{Tunnel B}

The tunnel $\mathrm{B}$ was rediscovered by the authors after opening a clearly anthropogenic passage that was hidden by fallen blocks (Figure 5). The passage gives access to a N45W oriented tunnel, $12 \mathrm{~m}$ long, $3 \mathrm{~m}$ wide and $1.5 \mathrm{~m}$ high (Figures 7A, Table 2). It represents the end portion of a tunnel whose exit to the surface is completely filled with a mixture of clay, sand, and sandstone blocks up to $30 \mathrm{~cm}$ wide (Figures 7B,C). This exit is parallel to tunnel A, but its roof is located approximately $50 \mathrm{~cm}$ below the floor of tunnel A (Figure 5). The shape of the tunnel is elliptical and its walls are smooth. The analysis of the surface structures of the walls is hindered by a clay coating formed due to occasional flooding of the tunnel.

\section{Tunnel C}

The existence of a third tunnel was inferred through an aperture located on the eastern wall of tunnel A, between meters 6.7 and 8 . This aperture nowadays is $4.5 \mathrm{~m}$ long and $2.5 \mathrm{~m}$ wide, but it is collapsed and partially filled with sand. The sandy infilling is more than $1 \mathrm{~m}$ thick, containing some large fallen slabs of sandstone. At the end of the cavity, the typical smooth and concave surfaces of the hosting rock against the infilling suggest the existence of a tunnel or chamber that may continue inside the hill.

\section{Surface morphology of the tunnel walls}

Of the three tunnels, only the surface morphology of the walls of tunnel A can be properly investigated. In tunnel B, the thin clay layer on the walls allows only the observation of the smooth surfaces and of a few digging traces. The walls of tunnel $\mathrm{C}$ are hidden behind the infilling. At tunnel $\mathrm{A}$, surface morphology of the walls is composed of five distinct features:

(i) traces that may be attributed to the fossorial paleovertebrates that produced the tunnel system are rare. At the front part of the tunnel, antrophogenic action has destroyed any possible traces. A detailed investigation from the $15.5^{\text {th }} \mathrm{m}$ up to the end of the tunnel showed that there are approximately 40 digging scratches at the Northern side and 8 digging scratches on the Southern side of tunnel A. The state of preservation of $75 \%$ of the marks is of very low quality; only $25 \%$ has a medium preservation degree, with better defined edges. Almost all scratches are oriented obliquely to the wall. Vertical and horizontal scratches are rare. More than $75 \%$ of the scratches are slightly sinuous, constituting very gentle arches. Regarding its size, the scratches form two groups. The largest group is composed of scratches with lengths between 8 and $14 \mathrm{~cm}$ and widths and depths of around $1 \mathrm{~cm}$. In five examples, two of these scratches are parallel, with 3.0 to $4.5 \mathrm{~cm}$ between the deepest points of the scratches (Figure 8B). In other two situations, three of these scratches are parallel, with 


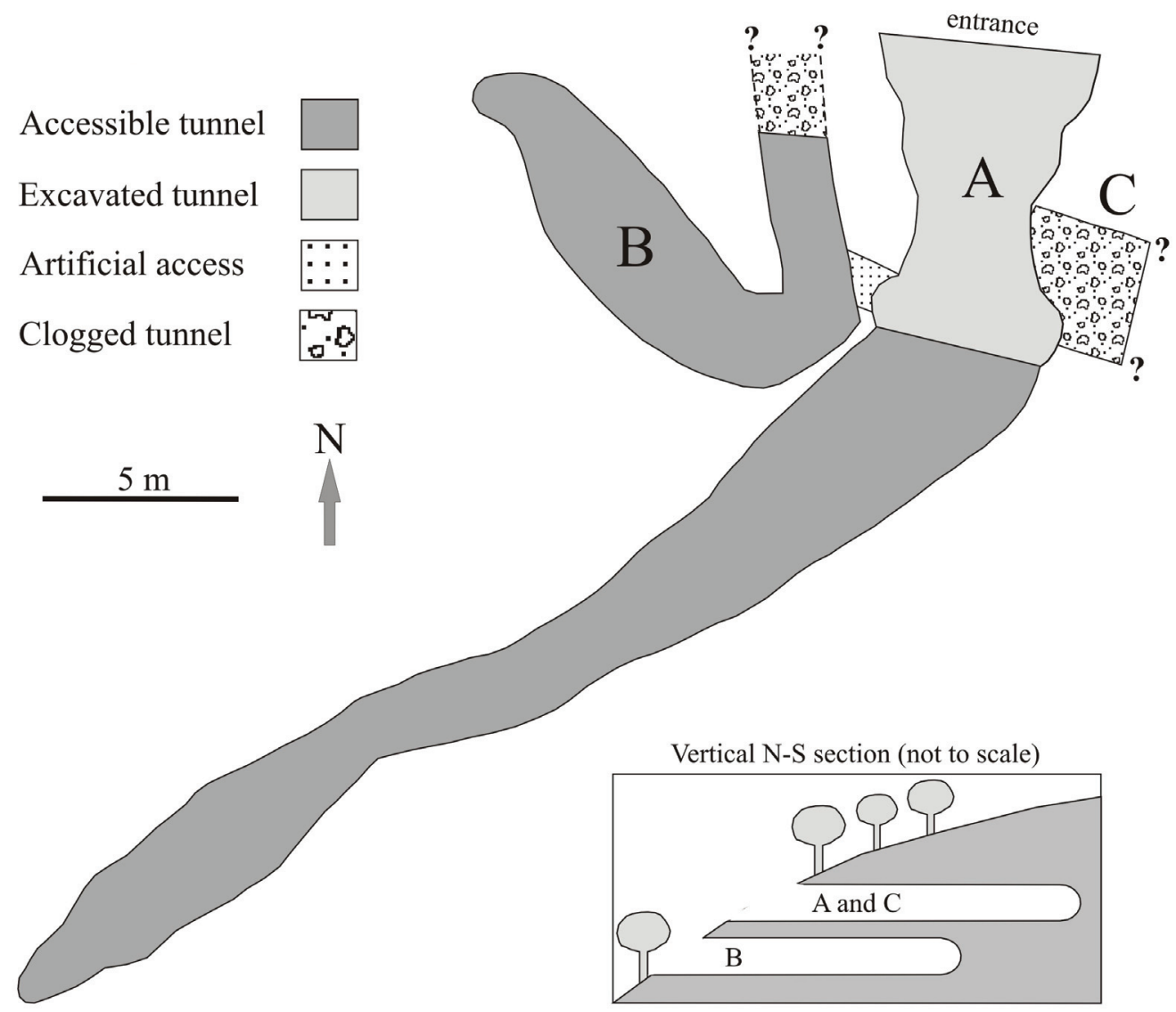

Figure 5. Floor plan and schematic vertical section (not to scale) of the three tunnels that compose the tunnel system of Boqueirão do Leão. The original and accessible portions of the tunnels also have some sedimentary infilling. Clogged portions are completely filled. Excavation of the front portion of tunnel A was made by a treasure hunter.

distances of 4.5 to $5.5 \mathrm{~cm}$ between deepest points. The second group is composed of digging scratches with lengths from 20 to $36 \mathrm{~cm}$, widths from 2 to $4 \mathrm{~cm}$ and depths up to $2.5 \mathrm{~cm}$. On one portion of the tunnel, there is a set of approximately ten scratches of this size. They are slightly sinuous, always oblique and with a low preservation degree (Figure 9A). At tunnel B, scratches are usually small, but on a single spot three parallel scratches are well defined (Figure 8C).

In the tunnel, three levels with distinct surface morphologies can be recognized (Figure 9B);

(ii) the roof and the lateral walls down to a level $20 \mathrm{~cm}$ beneath the highest point of the roof are completely smooth, without any distinct features (Figure 9C). The smooth surfaces on the roof and the sides can be followed until the end of the tunnel. There, a succession of concave and convex surfaces forms continuous smooth walls (Figure 6G);

(iii) the $2^{\text {nd }}$ level is located on the lateral walls approximately between 20 and $40 \mathrm{~cm}$ beneath the highest point of the roof. The smooth surfaces of level 1 continue, but are covered by a very regular network of black wormlike incrustations. Each one of these incrustations is 1 to $3 \mathrm{~mm}$ thick and several $\mathrm{cm}$ long (Figure 9D). The network of black incrustations covers extensive surfaces on tunnel A, but was not recognized in tunnel B;

(iv) the $3^{\text {rd }}$ level comprises the region of the lateral walls from beneath the $2^{\text {nd }}$ level up to the beginning of the infilling. Wall surfaces are covered by a continuous $1 \mathrm{~mm}$ thick layer of silica with superimposed straight or wheel-shaped crests (speleothems) around $1 \mathrm{~cm}$ thick (Figure 9E). A detailed mineralogical investigation of these speleothems surpasses the scope of this contribution. Water droplets that slowly emerge from the rock among the speleothems suggest that they also were formed by solutions derived from very slowly percolating underground waters enriched in $\mathrm{Si}, \mathrm{Fe}$ and $\mathrm{Mn}$;

(v) whereas the names and dates scratched by the visitors on the tunnels walls are easily recognized, the recognition of the pickax marks left by the treasure hunter is important to allow its distinction from the digging traces produced by paleovertebrates. The pick ax marks (Figure 9A) change almost half of the surface of the lateral walls exposed above the infilling. The action of the pickax consists of penetrating the rock up to a deepest point and pluck out a piece or slab of the rock by lever action. The action of an animal claw, instead, is just friction, producing a groove that enters and leaves the surface of the rock without tearing off pieces of the rock (Figure 8). Furthermore, as the tool marks are recent, its action exposes rock with the original light yellowreddish color. The much older digging traces are covered by the dark coating that lines the tunnel walls.

\section{DISCUSSION}

The identification of the "caves" of Boqueirão do Leão as a tunnel system produced by paleovertebrates considered 


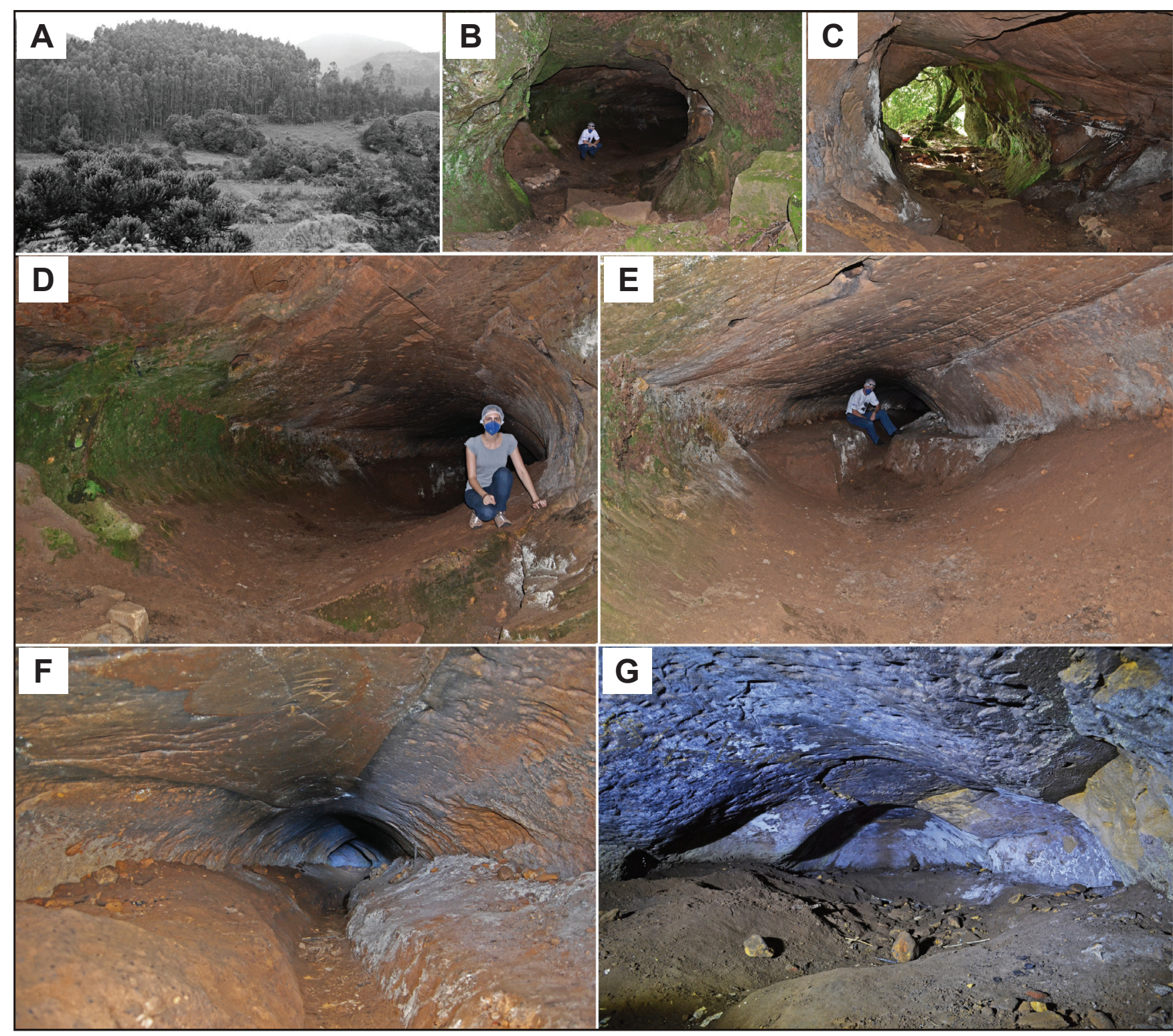

Figure 6. Aspects of the tunnel A of the tunnel system of Boqueirão do Leão. A, the system is located in the tree cluster in the middle of the picture. B, image of the entrance of tunnel A, excavated and destroyed by a treasure hunter. Person for scale. C, entrance seen from inside, devoid of any original feature. D, the preserved portion of the tunnel starts at the observer, with an elliptical outline $2.2 \mathrm{~m}$ high and $4.1 \mathrm{~m}$ wide. E, after the $15.5^{\text {th }}$ meter the infilling of the tunnel is preserved. The elliptical outline continues, but its width and height decrease. $\mathbf{F}$, the intermediate portion of the tunnel is well preserved and shows a remarkable sinuosity. The width at this point is of $\sim 2 \mathrm{~m}$. At the lateral walls there are many pickax marks and the anthropogenic trench continues until the $26^{\text {th }}$ meter. $\mathbf{G}$, image of the end of the tunnel, showing successive concave surfaces that repeat themselves on opposite lateral walls. Width of the picture $=\sim 3 \mathrm{~m}$.

the criterions of cave forming, general cave characteristics, geomorphology, lithology, structural characteristics and occurrence of digging traces.

Caves may be formed by several processes. The best known is the dissolution of carbonate rocks by underground waters, developing the "karst" topography and opening cavities of all possible sizes, usually with a large number of speleothems. Such features are absent in the tunnel system of Boqueirão do Leão. Another important process is the erosion by rainwater through discontinuities such as fractures and faults, very common in sandstones with a medium degree of lithification.

The state of preservation of the tunnels is the second aspect that has to be considered, as only original heights and widths of paleovertebrate tunnels allow progress in the discussion about the diggers. The sandstone in Boqueirão do Leão that hosts the tunnels has a medium to high lithification degree, because it is not friable but very tough when worked with tools. In general, these sandstones of the Botucatu Formation have a high preservation potential for paleovertebrate tunnels, as seen in other locations (Buchmann et al., 2009; Frank et al., 2010). Despite of the cross-stratification of the sandstone and the several fractures in the rock who favors, respectively, collapsing of rock slabs and erosion through pluvial waters, not any of such features has been observed and the dimensions of the tunnels thus can be considered as original.

An anthropogenic origin for the caves also has to be considered. Caves of this kind are known from several places 
Table 1. Measurements of tunnel A of the tunnel system of Boqueirão do Leão

\begin{tabular}{|c|c|c|c|c|}
\hline Distance from entrance $(\mathrm{m})$ & Width (m) & Height (m) & True Azimuth & Observations \\
\hline 0 & 5.60 & & \multirow{7}{*}{$5^{\circ}$} & \multirow{7}{*}{ Destroyed by antrhopogenic action } \\
\hline 1 & 5.20 & Open to sky & & \\
\hline 2 & 4.00 & & & \\
\hline 3 & 3.85 & 3.00 & & \\
\hline 4 & 2.90 & 2.50 & & \\
\hline 5 & 2.95 & 2.70 & & \\
\hline 6 & 3.55 & 2.60 & & \\
\hline 6.7 & \multicolumn{4}{|c|}{ Lateral anthropogenic openings on both sides } \\
\hline 8 & 4.12 & 2.50 & $5^{\circ}$ & \multirow{8}{*}{ Original tunnel from the $9^{\text {th }} \mathrm{m}$ on } \\
\hline 9 & 4.17 & 2.18 & \multirow{7}{*}{$50^{\circ}$} & \\
\hline 10 & 4.09 & 2.09 & & \\
\hline 11 & 3.09 & 2.03 & & \\
\hline 12 & 3.79 & 1.93 & & \\
\hline 13 & 3.64 & 1.89 & & \\
\hline 14 & 3.25 & 1.77 & & \\
\hline 15 & 2.89 & 1.57 & & \\
\hline 15.5 & - & - & \multirow{9}{*}{$60^{\circ}$} & \multirow{11}{*}{$\begin{array}{l}\text { Infilling } \sim 0.8 \mathrm{~m} \text { thick, with } \\
\text { anthropogenic trench in the middle }\end{array}$} \\
\hline 16 & 2.85 & 1.02 & & \\
\hline 17 & 2.65 & 1.00 & & \\
\hline 18 & 2.43 & 0.95 & & \\
\hline 19 & 2.00 & 0.85 & & \\
\hline 20 & 1.88 & 1.21 & & \\
\hline 21 & 1.97 & 1.22 & & \\
\hline 22 & 1.94 & 1.32 & & \\
\hline 23 & 1.91 & 1.38 & & \\
\hline 24 & 1.93 & 1.35 & \multirow{3}{*}{$75^{\circ}$} & \\
\hline 25 & 1.75 & 1.13 & & \\
\hline 26 & 1.60 & 0.80 & & \multirow{11}{*}{$\begin{array}{l}\text { Infilling of unknown thickness }(>0.8 \\
\text { m?) without anthropogenic trench }\end{array}$} \\
\hline 27 & 1.68 & 0.90 & \multirow{10}{*}{$55^{\circ}$} & \\
\hline 28 & 1.93 & 0.84 & & \\
\hline 29 & 2.33 & 0.91 & & \\
\hline 30 & 2.83 & 0.97 & & \\
\hline 31 & 2.64 & 0.95 & & \\
\hline 32 & 2.54 & 1.03 & & \\
\hline 33 & 2.36 & 0.82 & & \\
\hline 34 & 2.54 & 0.81 & & \\
\hline 35 & 1.57 & 0.68 & & \\
\hline 36 & 1.35 & 0.50 & & \\
\hline
\end{tabular}

in the world like Derinkuyu (Turkey) and Central Europe (the "Erdstall" structures). Man-made caves usually show rectangular outlines and walls covered with tool marks. In Brazil, they are very unlikely because South American natives knew no metals and, therefore, had no proper tools for digging. On the other hand, the reoccupation of paleovertebrate tunnels by Indians was documented in the State of Santa Catarina (Brazil), in regions of cold climate (Rohr, 1971).

The sediments that fill partially the tunnel A, the former portion of tunnel $\mathrm{B}$ and completely the tunnel $\mathrm{C}$ are allochthonous. This infilling, formed of clays, sand and sandstone blocks, most probably was brought in by the river that flows only $80 \mathrm{~m}$ from the tunnel entrances (Figure 6A), at a level that is approximately $10 \mathrm{~m}$ lower. This origin is compatible with the fact that the infilling of the lower tunnel B contains large $(\sim 30 \mathrm{~cm})$ sandstone blocks whereas in the upper tunnels $\mathrm{A}$ and $\mathrm{C}$, sandstone blocks are almost absent. In the same way, it explains why there is a spot without infilling in the chamber of tunnel B. This spot is located exactly at the point where a hypothetical water current, entering through the tunnel entrance, forms a whirlpool, distributing sediments around it but not at it (Figure 7B). This observations suggest that the sedimentary infilling of the tunnels was deposited during cycles of flooding.

Digging scratches on opposite lateral walls of a paleovertebrate tunnel also are indicative of at least partial paleovertebrate construction of the tunnel and of the preservation of the original size. In the tunnels of Boqueirão do Leão, the sediments are hiding approximately the lower 

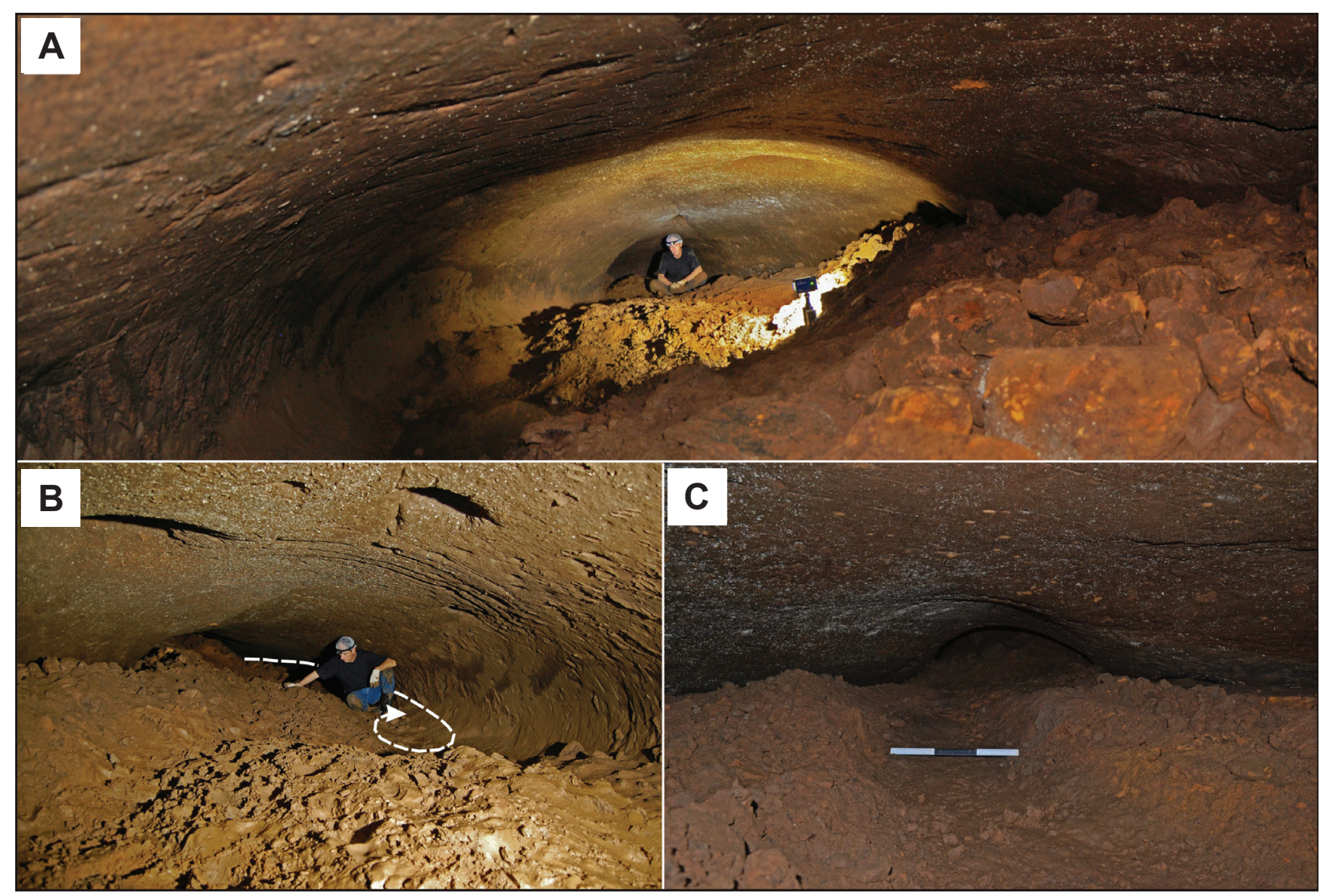

Figure 7. Aspects of the tunnel B of the tunnel system of Boqueirão do Leão. A, view of the access towards NW (end of the tunnel). At right, sandstone blocks mixed with sand and clays can be seen. B, view from the end of the chamber towards the access (towards SE). Arrow shows the probable flow direction of the water stream that filled the tunnel with sediments (see Discussion). C, view of the tunnel exit, clogged with clay, sand and sandstone blocks. Scale bar $=30 \mathrm{~cm}$.

half of the lateral walls of tunnel A, but the upper exposed portion shows digging scratches. At several spots there are 2 or even 3 parallel scratches, mirroring possibly the autopodium of the tunnel diggers (Figures 9B,C). Unlike clayey rocks that preserve even delicate details of the traces, sandstones preserve only the thicker traces.

Claw scratches may have been produced by animals who reoccupied the tunnels after the tunnel producers abandoned them. Reoccupation of vertebrate burrows is very frequent, as in the tunnels of the aardvark Orycteropus afer (Pallas, 1766) (Knöthig, 2005, p. 36-37) and of the gopher-tortoise Gopherus polyphemus Daudin, 1802 (Kent et al., 1997). Tunnels of both species are used by many tens of species of vertebrates and invertebrates, even during the use of the tunnel by the digger. Given this uncertainty, digging scratches not necessarily can be assigned always to the original tunnel digger but have to be interpreted carefully.

The roofs and the upper portions of the lateral walls of tunnels A and B are notably smooth. In other paleovertebrate tunnels the situation is exactly the opposite: the roof usually displays the largest number and the best preserved digging scratches, since these surfaces do not get more in contact with the bodies of the diggers after the excavation phase. The smooth surfaces are not a result of erosion, since they are continuous and perfectly coincident with the elliptical section of the tunnels. Erosion by flowing waters derived from the river in front of the tunnels, for example, would have erased also the scratches on the lower portion of the lateral walls, where they are still present. A plausible origin for these smooth surfaces is that they were produced by the continuous touching and rubbing of the back of the paleovertebrates at the roof and lateral walls during the time the tunnels were in use. This continuous contact erased the scratches and produced the smooth surfaces at the upper portions of the tunnels, but preserved the scratches on the lower portions. It also explains the fact that the only preserved set of scratches in tunnel A is located on a more protected concave portion of the lateral wall. In this way, the tunnels must have been used by very large fossorial animals during a long time.

The original widths of the tunnels are one of the most important indications about the body size of the tunnel diggers. Extant fossorial vertebrates and invertebrates dig burrows only as wide as or slightly wider than its bodies. Several examples can be enrolled. The largest living armadillo, Priodontes maximus Kerr, 1792, is the biggest extant fossorial South American animal. Despite of its body size of around $55 \mathrm{~kg}$, its tunnels are only $43 \mathrm{~cm}$ wide and $36 \mathrm{~cm}$ high, in average (Srbek-Araújo et al., 2009; Eduardo Fernandez-Duque, pers. comm., 2010). Of similar diameters $(\sim 40 \mathrm{~cm})$ are the tunnels of the largest extant fossorial 


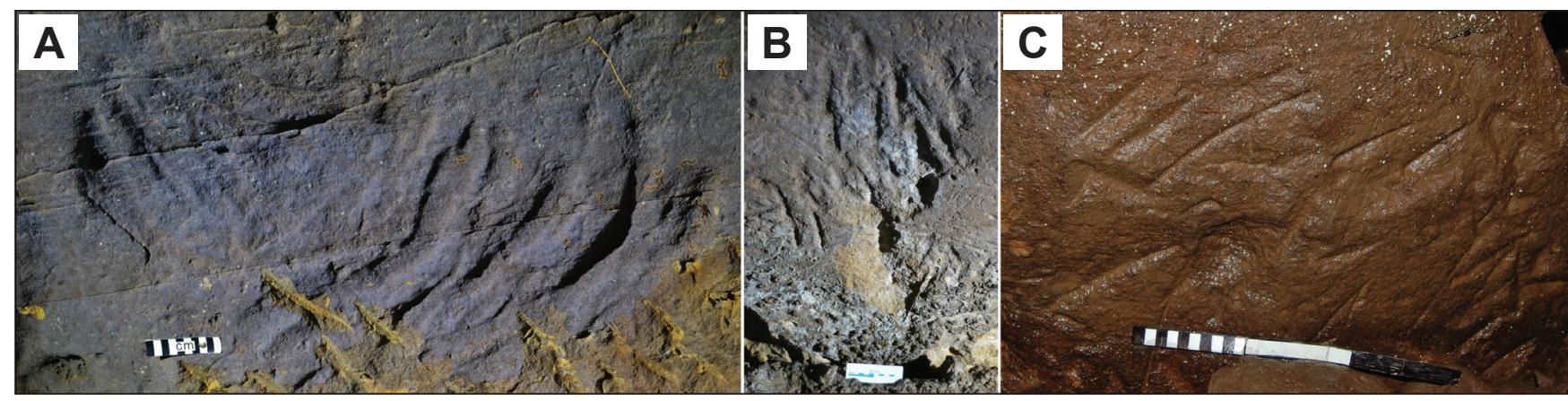

Figure 8. Digging scratches at the walls of tunnels A and B. A, set of big-sized scratches preserved on a concave portion of the lateral wall of tunnel A. B, Comparison between two smaller-sized parallel scratches (at left) and some big scratches (at right) in tunnel A. C, three parallel scratches on the wall of tunnel $B$. Scale bars: $A, B=10 \mathrm{~cm} ; C=20 \mathrm{~cm}$

African animal, the aardvark (Knöthig, 2005, p. 38), whose body mass if of up to $80 \mathrm{~kg}$. Other fossorial vertebrates, like foxes, badgers and moles, also dig tunnels whose width fits closely the body width of the diggers. Only inside their tunnels systems larger chambers can be found (e.g. The Badger Trust, 2012). The same reasoning may be applied to the fossorial paleovertebrates. The diggers of the tunnels of Boqueirão do Leão, therefore, need to be found among the South American paleovertebrates of the megafauna, defined as composed by the large mammals whose body mass exceeds a few hundreds of kg (Fariña \& Vizcaíno, 1995).

Members of the South American Megafauna known so far from Rio Grande do Sul include Pleistocene taxa such as sabertoothed cats (Smilodon Lund, 1841), bears (Arctotherium Burmeister, 1879), proboscideans (Stegomastodon Pohlig, 1912), litopterns (Macrauchenia Owen, 1838), toxodonts (Toxodon Owen, 1837), llamas (Lama guanicoe (Müller, 1776), Hemiauchenia Gervais \& Ameghino, 1880), horses (Equus Linnaeus, 1758; Hippidion Owen, 1869), glyptodonts (Glyptodon Owen, 1839; Panochthus Burmeister,1866; Doedicurus Burmeister, 1874; Neuryurus Ameghino, 1889), ground sloths (Megatherium, Cuvier, 1796; Eremotherium Spillmann, 1948; Glossotherium Owen, 1840; Lestodon Gervais, 1855; Mylodon Owen, 1840; Catonyx Lund, 1839) and giant armadillos (Pampatherium Ameghino, 1875; Holmesina Simpson, 1930; Propraopus Ameghino, 1881) (Lopes \& Buchmann, 2011). Among these taxa, those with morphological adaptations to dig are only the armadillos and the ground sloths (Bargo et al., 2000).

The smaller Cenozoic armadillos are Propraopus and Eutatus Gervais, 1867, with lengths are of $1.5 \mathrm{~m}$, weights of around $50 \mathrm{~kg}$ and body widths of some $50 \mathrm{~cm}$ (Farina \& Vizcaíno, 1995; Vizcaíno et al., 2001). Among the megafauna, the armadillos Holmesina septentrionalis (Leidy) Simpson, 1930 and Pampatherium typum Ameghino, 1875 had weights of approximately $200 \mathrm{~kg}$ (Farina \& Vizcaíno, 1995; Fariña, 1996), and a maximum body width of $80 \mathrm{~cm}$ (Vizcaíno et al., 2001, p. 292). With body widths in this range, armadillos cannot be considered as the diggers of the tunnels of Boqueirão do Leão, since the widths of the tunnels equals to 5 of the biggest known armadillos side by side.

Ground sloths, on the other hand, are of another size range. Scelidotherium Owen, 1840 weighted around 800 and $1,000 \mathrm{~kg}$,
Glossotherium around 1,500 kg, Mylodon from 1,000 to 2,000 $\mathrm{kg}$, Lestodon some 4,000 $\mathrm{kg}$ and Megatherium, the biggest one, some 6,000 kg (Fariña \& Vizcaíno, 1995; Fariña et al., 1998). This body mass range allows its comparison with cattle (full-grown bulls) and elephants to figure out its body width, which must have been of less than $1.3 \mathrm{~m}$ for Mylodontidae and slightly more for Megatheriidae. The tunnels of Boqueirão do Leão, therefore, are of the necessary size to be frequented by large ground sloths. Two questions relate to the fact that the tunnels are much wider than the width of the largest known sloths, especially considering that Megatherium probably was not a digger (Bargo et al., 2000), the same applying to Eremotherium.

One of the main reasons that vertebrate burrows have only the width of the bodies of their diggers is to avoid the access of larger predators. This reason most probably do not apply to the tunnels of Boqueirão do Leão, because the largest predators of the South American megafauna were the saber-thooted tigers (Smilodon populator Lund, 1842) and probably the bears (Arctotherium), both with body masses below than $500 \mathrm{~kg}$ (Fariña et al., 1998); much smaller than the sloths. Therefore, the main function of the tunnels was not protection from predation.

The impressive volume of removed sandstone to dig the tunnels of Boqueirão do Leão offers hints about the construction and the occupation of the tunnels. The original volume of tunnel A ranges between 150 and $200 \mathrm{~m}^{3}$; the shorter tunnel B probably have a volume of half of that values. Each cubic meter of sandstone corresponds to the removal of more than two tons of excavated loose sand. The huge amount of energy required to excavate tunnels the size of the ones of Boqueirão do Leão turns it hard to conceive that a single sloth have excavated it. In the same way, the size far exceeds that necessary for a single animal. Most likely, several generations of sloth herds have constructed the tunnels, expanding them slowly, year after year. This means that the occupation of the tunnels of Boqueirão do Leão contrasted with the behavior of most recent large fossorial mammals, who occupy its tunnels only over short periods like a few weeks as the African aardvark does (Knöthig, 2005, p. 36). This size of the tunnels suggests that sloth herds occupied it over a long time, using this very appropriate place (close to waterways, with good insulation, etc.) to turn the tunnels into a more or 
Table 2. Measurements of tunnel B of the tunnel system of Boqueirão do Leão.

\begin{tabular}{|c|c|c|c|c|}
\hline Distance from access (m) & Width & Height & True Azimuth & Observations \\
\hline 2 & 2.75 & \multirow{11}{*}{$\begin{array}{l}1.5 \mathrm{~m} \text { on the least } \\
\text { clogged spot }\end{array}$} & \multirow{11}{*}{$\sim 70^{\circ}$} & \multirow{11}{*}{$\begin{array}{l}\text { Partially clogged with mud, } \\
\text { sand and rock slabs }\end{array}$} \\
\hline 3 & 3.00 & & & \\
\hline 4 & 3.20 & & & \\
\hline 5 & 3.50 & & & \\
\hline 6 & 3.75 & & & \\
\hline 7 & 3.50 & & & \\
\hline 8 & 3.00 & & & \\
\hline 9 & 2,45 & & & \\
\hline 10 & 3.55 & & & \\
\hline 11 & 2.75 & & & \\
\hline 11.5 & end & & & \\
\hline
\end{tabular}

less permanent shelter. Extant badgers in Europe and Asia have developed similar behavior (The Badger Trust, 2012).

Of a much more speculative character are the considerations about the age of the tunnels of Boqueirão do Leão and of the motifs of the paleovertebrates in digging tunnels of these sizes in such a tough rock.

The tunnels must be recent considering the drainage that flows $80 \mathrm{~m}$ of the tunnel entrances, at a level, which is only $10 \mathrm{~m}$ lower. The dissected plateau of the Boqueirão do Leão region fits with Stage 2 of the Geographic Cycle, during which the carving of the river valleys down to base level is a geologically fast process (Pazzaglia, 2003). The humid sub-tropical climate of Southern Brazil speeds this process. In the current landscape, the tunnels are not located on a suspended older fluvial terrace; they rather "fit" perfectly into the landscape, still being an excellent place for a shelter. Thus, we consider that it is most probable that the tunnels are less than $100 \mathrm{ka}$ old.

The motifs for the excavation of tunnels by the sloths may be related to drier paleoclimates. Today, the tunnels are inhabitable because they are too wet. We have seen running water in almost all paleovertebrate tunnels during our inspections. Even in very dry periods or during droughts, most of the tunnels are very humid. In rainy periods, tunnels with water dripping from the roof, flowing on the floor and/ or entering the tunnel through small cracks and pores at the walls are commonplace. The huge and constant amount of clean water even allowed the use of some of the tunnels as water suppliers by the landowners, as if they were horizontal wells. This humidity demonstrates that the tunnels have been excavated during dryer periods, probably to protect its diggers either from hot or cold climates. Extant armadillos, for example, do not dig for shelter in water soaked sediments, and abandon burrows dug in riverbanks when the water table rises (Taber, 1945). Several testimonies of more arid (and colder) paleoclimates have been registered in South America during the Quaternary. The analysis of the landscape evolution in the Buenos Aires Province (Argentina), for example, showed that loess deposition, characterizing arid and cold climates, occurred during late Pleistocene (Quattrocchio et al., 2008). Still earlier, the paleovertebrate content of the Guerrero Member of the Luján Formation (Argentina), formed under colder and drier conditions between $\sim 29.850$ and 10.290 years AP, is composed of remains of Glossotherium, Scelidotherium and Megatherium. However, in the lower La Chumbiada Member of the same formation, formed under warm and dry conditions around $30 \mathrm{ka}$ AP, such taxa are not recorded (Prado \& Alberdi, 1999; Tonni et al., 1999). More to the north, palynological analysis near the city of Brasília (Brazil) indicated a cooler period between ca. 24,000 and 21,450 $\pm 100 \mathrm{yr}$ BP (Barberi et al., 2000). The shelter need of sloths is registered by several findings of sloth remains in natural caves (Vizcaíno et al., 2001), as in the touristic Mylodon cave in Patagonia (Chile). Therefore, sloth herds with some kind of shelter and hibernating needs, among others, during drier and colder paleoclimates are a way to understand large and long tunnels.

The linking of the tunnels to a specific ground sloth genus is not possible at now. Burrows measuring $1.8 \mathrm{~m}$ in diameter and $1.2 \mathrm{~m}$ in height in the Pampean Region of Argentina were attributed to mylodontid sloths of the genera Glossotherium and Scelidotherium (Bargo et al., 2000; Vizcaíno et al., 2001). The tunnels of Boqueirão do Leão, much bigger, may have been dug by the largest mylodontids of the genus Lestodon. Bargo et al. (2000) stated that Lestodon apparently would not be able to dig, although its limb proportions were similar to possible diggers such as Glossotherium and Scelidoherium. However, given the huge tunnels found in southern Brazil, much larger than those found in Argentina and attributed to Glossotherium and Scelidotherium, it is possible that this taxon could have also been a digger. In future, with the discovery of more tunnels with better-preserved claw marks, it may be possible to advance in this direction.

\section{FINAL REMARKS}

Despite of varying degrees of sedimentary infilling and of the anthropogenic partial destruction, the remaining features of the tunnel system located in Boqueirão do Leão allow its definition as tunnels excavated by Cenozoic vertebrates. The widths of the tunnels suggest that they have been excavated by ground sloths. The length and the huge amount of excavated rock suggests that the tunnels were not excavated by a single animal, but slowly by several generations of sloth herds during a long time, as a shelter from drier paleoclimates and not to 

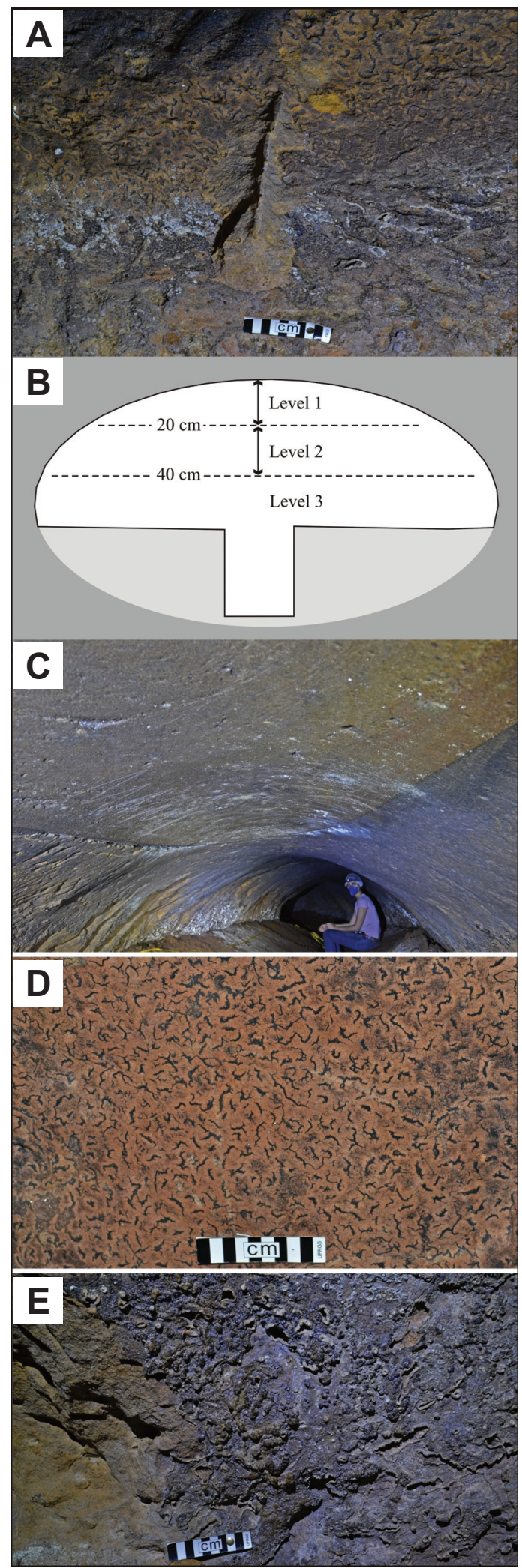

Figure 9. Surface morphology of the walls of tunnel A. A, typical pickax mark. At the lower end, a rock piece was plucked out by lever action. The mark exposes rock with a lighter color than the original wall surface. B, schematic section of the tunnel with the three levels with distinct surface morphologies (see text). C, level 1: the roof and the upper portion of the lateral walls are smooth. Observer for scale. D, level 2: wormlike incrustations on smooth walls. E, level 3: speleothems at the walls. At left, the speleothems were destroyed by tool action. Scale bars $=10 \mathrm{~cm}$. avoid predators. The tunnel system evidences the shelter need of ground sloths, whose dispersion turns possible the existence of similar tunnel systems in an intercontinental scale, given the necessary prerequisites of a favorable topography and excavatable sediments or altered rocks. Better-preserved tunnel systems may allow, in future, progress in the definitions about the tunnel builders.

\section{ACKNOWLEDGMENTS}

The authors want to thank the biologist W.J. Weschenfelder, whose pictures in the Internet suggested that the "Indian cave" of Boqueirão do Leão could be a paleovertebrate tunnel. Thanks also to the reviewers of both versions of this manuscript. Research partially funded by project CNPq 401772/2010-1.

\section{REFERENCES}

Barberi, M.; Salgado-Labouriau, M.L. \& Suguio, K. 2000. Paleovegetation and paleoclimate of "Vereda de Águas Emendadas", central Brazil. Journal of South American Earth Sciences, 13:241-254. doi:10.1016/S0895-9811(00)00022-5

Bargo, M.S.; Vizcaino, S.F.; Archuby, F.M. \& Blanco, R.E. 2000. Limb bone proportions, strength and digging in some Lujanian (Late Pleistocene - Early Holocene) mylodontid ground sloths (Mammalia, Xenarthra). Journal of Vertebrate Paleontology, 20:601-610. doi:10.1671/0272-4634(2000)020[0601:LBPSA D]2.0.CO;2

Bergqvist, L.P. \& Maciel, L. 1994. Icnofósseis de Mamíferos (Crotovinas) na Planície Costeira do Rio Grande do Sul, Brasil. Anais da Academia Brasileira de Ciências, 66:189-197.

Bitencourt, M.F. \& Nardi, L.V. S. 2000. Tectonic setting and sources of magmatism related to the Southern Brazilian shear belt. Revista Brasileira de Geociências, 30:184-187.

Bitencourt, M.F.; Bongiolo, E.M.; Philipp, R.P.; Morales, L.F.G.; Rubert, R.R.; Melo, C.L. \& Luft Junior, J.L. 2008. Estratigrafia do Batólito Florianópolis, Cinturão Dom Feliciano, na região de Garopaba - Paulo Lopes, SC. Pesquisas em Geociências, 35:109-136.

Bromley, R. 1990. Trace Fossils: biology and taphonomy. London, Unwyn Hyman, 280 p. (Special Topics in Palaeontology, 9).

Buchmann, F.S.C.; Caron, F; Lopes, R.P. \& Tomazelli, L.J. 2003. Traços fósseis (paleotocas e crotovinas) da megafauna extinta no Rio Grande do Sul, Brasil. In: CONGRESSO DA ASSOCIAÇÃO BRASILEIRA DE ESTUDOS DO QUATERNÁRIO, 9, 2003. Anais, Recife, 1 CD-ROM.

Buchmann, F.S.; Lopes, R.P. \& Caron, F. 2009. Icnofósseis (Paleotocas e Crotovinas) atribuídos a mamíferos extintos no sudeste e sul do Brasil. Revista Brasileira de Paleontologia, 12:247-256. doi:10.4072/rbp.2009.3.07

Buatois, L.A. \& Mángano, M.G. 2011. Ichnology: organism substrate interactions in space and time. Cambridge, Cambridge University Press, 370 p. doi:10.1017/S0016756811001038

Dondas, A.; Isla, F.I. \& Carballido, J.L. 2009. Paleocaves exhumed from the Miramar Formation (Ensenadan stage-age, Pleistocene), Mar del Plata, Argentina. Quaternary International, 210:44-50. doi:10.1016/j.quaint.2009.07.001

Fariña, R.A. \& Vizcaíno, S.F. 1995. Hace solo diez mil años. $6^{\mathrm{a}}$ ed. Montevideo, Editorial Fin de Siglo, 123 p., 1 DVD.

Fariña, E.A. 1996. Trophic relationships among Lujanian mammals. Evolutionary Theory, 11:125-134. 
Fariña, R.A.; Vizcaíno, S.F. \& Bargo, N.S. 1998. Body mass estimations in Lujanian (Late Pleistocene-Early Holocene of South América) mammal megafauna. Mastozoologia Neotropical, 5:87-108.

Frank, H.T.; Gomes, M.E.B. \& Formoso, M.L.L. 2009. Review of the areal extent and the volume of the Serra Geral Formation, Paraná Basin, South America. Pesquisas em Geociências, 36:49-57.

Frank, H.T.; Caron, F.; Lima, L.G.; Lopes, R.P.; Fornari, M. \& Buchmann, F.C.S. 2010. Uma caverna formada por processos biofísicos e geológicos: a paleotoca do Arroio da Bica (Nova Hartz, Rio Grande do Sul, Brasil). In: SIMPÓSIO SULBRASILEIRO DE ESPELEOLOGIA, 2, 2010. Anais, Ponta Grossa, 1 CD-ROM.

Garland, F.; Hawkesworth, C.J. \& Mantovani, M.S.M. 1995. Description and petrogenesis of the Paraná rhyolites, Southern Brazil. Journal of Petrology, 36:1193-1227. doi: 10.1093/ petrology/36.5.1193

Groenewald, G.H. 1991. Burrow casts from the LystrosaurusProcolophon assemblage-zone, Karoo sequence, South Africa. Koedoe, 34:13-22. doi: 10.4102/koedoe.v34i1.409

Jerram, D.A.; Mountney, N.P.; Howell, J.A.; Long, D. \& Stollhofen, H. 2000. Death of a sand sea: an active eolian erg systematically buried by the Etendeka flood basalts of NW Namibia. Journal of the Geological Society, 157:513-516. doi: 10.1144/jgs.157.3.513

Kent, D.M.; Langston, M.A.; Hanf, D.W. \& Wallace, P.M. 1997. Utility of a camera system for investigating gopher tortoise burrows. Florida Scientist, 60:193-196.

Knöthig, J. 2005. Biology of the aardvark (Orycteropus afer). Fakultät für Biowissenschaften der Ruprecht-Karls-Universität Heidelberg. Diplomarbeit, 212 p.

Lopes, R.P. \& Buchmann, F.S.C. 2011. Pleistocene mammals from the southern Brazilian continental shelf. Journal of South American Earth Sciences, 31:17-27. doi: 10.1016/ jsames.2010.11.003

Martin, A. 2009. Dinosaur burrows in the Otway Group (Albian) of Victoria, Australia, and their relation to Cretaceous polar environments. Cretaceous Research, 30:1223-1237. doi: 10.1016/j.cretres.2009.06.003

Mercosul 2001. Subgrupo de Trabalho 9. Comissão temática de geologia e recursos minerais. Mapa de integração geológica da bacia do Prata e áreas adjacentes. Porto Alegre. CPRM, 1 mapa, 4 partes, col. escala: 1:2.500.000.

Milani, E.J.; Faccini, U.F.; Scherer, C.M.; Araújo, L.M. \& Cupertino, J.A. 1998. Sequences and stratigraphic hierarchy of the Paraná Basin (Ordovician to Cretaceous), Southern Brazil. Boletim IG-USP, 29:125-173.

Miller, M.F.; Hasiotis, S.T.; Babcock, L.E.; Isbell, J.L. \& Colllinson, J.W. 2001. Tetrapod and large burrows of uncertain origin in Triassic high paleolatitude floodplain deposits, Antarctica. Palaios, 16:218-232. doi:10.1669/0883-1351(2001)016<0218:TALBO $U>2.0 . C O ; 2$

Modesto, S.P. \& Botha-Brink, J. 2010. A burrow cast with Lystrosaurus skeletal remains from the Lower Triassic of South Africa. Palaios, 25:274-281. doi:10.2110/palo.2009.p09-077r

Padberg-Drenkpol, P. 1933. Mysteriosas Galerias Subterrâneas em Santa Catarina. Boletim do Museu Nacional, 9.

Pazzaglia, F.J. 2003. Landscape evolution models. In: Gillespie, A.R., Porter, S.C. \& Atwater, B.F. (eds.) The Quaternary period in the United States, development in Quaternary Science, 1:247-274.

Peate, D.W. 1997. The Paraná-Etendeka Province. In: J.J. Mahoney \& C.C. Coffin (eds.) Large igneous provinces: continental, oceanic and planetary flood volcanism, p. 217-245. doi:10.1029/ GM100 (Geophysical Monograph Series 100).

Popa, M.E. \& Kedzior, A. 2006. Preliminary results on the Steierdorf Formation in Anina, Romania. In: Z. Csiki, (ed.) Mesozoic and Cenozoic vertebrates and paleoenvironments, Ars Docendi, p. 197-201.

Prado, J.L. \& Alberdi, M.T. 1999. The mammalian record and climatic change over the last 30.000 years in the Pampean region, Argentina. Quaternary International, 57/58:165-174. doi:10.1016/S1040-6182(98)00057-3

Prous, A. 1991. Arqueologia brasileira. Brasília, Editora Universidade de Brasília, $607 \mathrm{p}$.

Quattrocchio, M.E.; Borromei, A.M.; Deschamps, C.M.; Grill, S.C. \& Zavala, C.A. 2008. Landscape evolution and climate changes in the Late Pleistocene-Holocene, southern Pampa (Argentina): evidence from palynology, mammals and sedimentology. Quaternary International, 181:123-138. doi:10.1016/j. quaint.2007.02.018

Quintana, C.A. 1992. Estructura interna de uma paleocueva, posiblemente de um Dasypodidae (Mammalia, Edentata) del Pleistoceno de Mar del Plata (Provincia de Buenos Aires, Argentina). Ameghiniana, 29:87-91.

Riese, D.J.; Hasiotis, S.T. \& Odier, G.P. 2011. Synapsid burrows and associated trace fossils in the Lower Jurassic Navajo sandstone, Southeastern Utah, U.S.A., indicates a diverse community living in a wet desert ecosystem. Journal of Sedimentary Research, 81:299-325. doi:10.2110/jsr.2011.25

Rohr, J.A. 1971. Os sítios arqueológicos do Planalto Catarinense, Brasil. São Leopoldo, Instituto Anchietano de Pesquisas (Antropologia 24).

Seilacher, A. 1953. Studien zur Palichnologie: 1. Über die Methoden der Palichnologie. Neues Jahrbuch fur Geologie und Paläontologie, Abhandlungen, 96:421-452.

Self, S.; Keszthelyi, L.; Thordarson, Th. 1998. The importance of Pahoehoe. Annual Review of Earth and Planetary Science Letters, 26:81-110. doi: 10.1146/annurev.earth.26.1.81

Sidor, C.A.; Miller, M.F. \& Isbell, J.L. 2009. Tetrapod burrows from the Triassic of Antarctica. Journal of Vertebrate Paleontology, 28:277-284. doi: 10.1671/0272-4634(2008)28[277:TBFTTO ]2.0.CO;2

Smith, R.M.H. 1987. Helical burrow casts of therapsid origin from the Beaufort Group (Permian) of South Africa. Palaeogeography, Palaeoclimatology, Palaeoecology, 60:155169. doi:10.1016/0031-0182(87)90030-7

Srbek-Araújo, A.C.; Scoss, L.M.; Hirsch, A. \& Chiarello, A.G. 2009. Records of the giant-armadillo Priodontes maximus (Cingulata: Dasypodidae) in the Atlantic Forest: are Minas Gerais and Espírito Santo the last strongholds of the species? Zoologia, 26:461-468. doi:10.1590/S1984-46702009000300010

Storm, L.; Needle, M.D.; Smith, C. J.; Fillmore, D.L.; Szajna, M.; Simpson, E.L. \& Lucas, S.G., 2010. Large vertebrate burrow from the Upper Mississippian Mauch Chunk Formation, eastern Pennsylvania, USA. Palaeogeography, Palaeoclimatology, Palaeoecology, 298:341-347. doi:10.1016/j.palaeo.2010.10.018

Taber, F. 1945. Contribution on the life history and ecology of the nine-banded armadillo. Journal of Mammalogy, 26:211-226.

Talanda, M.; Dziecio, S.; Sulej T. \& Wiedzki, G.N. 2011. Vertebrate burrow system from the upper Triassic of Poland. Palaios, 26:99105. doi:10.2110/palo.2010.p10-024r

The Badger Trust. 2012. Eurasian Badger Factsheet. Available at http://www.nfbg.org.uk/_Attachments/Resources/283_S4.pdf; accessed on January 10. 
Tonni, E.P.; Cione, A.L. \& Figini, A.J. 1999. Predominance of arid climates indicated by mammals in the pampas of Argentina during the late Pleistocene and Holocene. Palaeogeography, Palaeoclimatology, Palaeoecology, 147:257-281. doi: 10.1016/ S0031-0182(98)00140-0

Varrichio, D.J.; Martin, A.J. \& Katsura, Y. 2007. First trace and body fossil evidence of a burrowing, denning dinosaur. Proceedings of the Royal Society B, 274:1361-1368. doi: 10.1098/rspb.2006.0443

Villwock, J.A.; Tomazelli, L.J.; Loss, E.L.; Dehnhardt, E.A.; Horn, N.O.; Bachi, F.A. \& Dehnhardt, B.A. 1986. Geology of the Rio Grande do Sul coastal province. Quaternary of the South America and Antarctic Peninsula, 4:79-97.

Veiga, P. 1973. Estudo dos arenitos "intertrapps" da Formação Serra Geral na região de Santa Maria, RS. Programa de Pós-
Graduação em Geociências, Universidade Federal do Rio Grande do Sul, M.Sc. thesis, 100 p.

Vizcaíno, S.F.; Zárate, M.; Bargo, S.M. \& Dondas, A. 2001. Pleistocene burrows in the Mar del Plata área (Argentina) and their probable builders. Acta Palaeontologica Polonica, 46:289-301.

Voigt, S.; Schneider, J.W.; Saber, H.; Hminna, A.; Lagnaoui, A.; Klein, H.; Brosig, A. \& Fischer, J. 2011. Complex tetrapod burrows from Middle Triassic red beds of the Argana Basin (Western High Atlas, Morocco). Palaios, 26:555-566. doi:10.2110/palo.2011.p11-014r

Zárate, M.A.; Bargo, M.S.; Vizcaíno, S.F.; Dondas, A. \& Scaglia, O. 1998. Estructuras biogênicas en el Cenozoico tardio de Mar del Plata (Argentina) atribuibles a grandes mamíferos. Revista da Asociación Argentina de Sedimentología, 5:95-103.

Received in February, 2012; accepted in January, 2013. 